\title{
CULTURAL POLICIES. THE FIRST DECADE OF THE LA FONTAINE LITERATURE SOCIETY (1920-1930)
}

\author{
ILDIKÓ P. VARGA \\ Babeș-Bolyai University, Cluj-Napoca \\ ildikovus@yahoo.com
}

\begin{abstract}
The La Fontaine Literature Society was founded in 1920 in Budapest. Its task was to promote the world literature in Hungary and to make Hungarian literature better known abroad.

One of the founders was Béla Vikár, who also translated the Fables of Jean La Fontaine into Hungarian. In my paper I investigate his correspondence between 1920 and 30 and the deed of foundation of the La Fontaine Society. My aim is to describe the place and the role of Finnish and Estonian literatures in the Society's work.
\end{abstract}

Keywords: La Fontaine Literature Society, Béla Vikár, Finnish literature, Estonian literature, translations

The La Fontaine Literature Society was founded in 1920 in Budapest. The objectives of the society include the translation and introduction of the valuable works of world literature and Hungarian literature, as well as the presentation of these to the public at various literary evenings and matinees.

My choice of topic is mainly motivated by the fact that the history of this society and the description of its activities have not been addressed systematically so far. András Laczkó (1989: 85-93) investigated only Béla Vikár's ${ }^{1}$ role in the life of the society. In his writing, the author highlighted among the activities of the society the presentation of Russian literature and that of the socialist block, although he admitted that "they worked with the literature of every European country." The activity of the society, I think, was more versatile and more diverse than it has been assumed and revealed so far. This organisation defining itself as a society for world literature, unlike its name, is not only open to French culture, but it sought to cover European literature through its activities. In addition to the large languages and literatures, smaller ones were also present: from Northern European ones to those of countries adjacent to Hungary, as well as Southern European literature.

In my study, I examine the first ten years of the La Fontaine Society's operation, especially the role of Finnish and Estonian literature in the activities of the society. For my analysis, I use the letters ${ }^{2}$ written by Béla Vikár (founder, general secretary and, from 1932, chair of the society) and the statutes of the society. 


\section{Questions and Presuppositions}

György C. Kálmán distinguishes three elements in the program of literary societies: "to bring together those who share similar values, whose tastes are close to each other. Even if not on the basis of their aim and program, but in terms of their results, this may mean that certain critical and interpretative principles and practices (or concepts defining creation) may have been formed, discussed, stabilized - and occasionally made public. On the other hand, these societies are advocacy organisations that protect the interests of members (writers, critics, literature mediators) and literary texts (their distribution, interpretation) the society focuses on. [...] Thirdly, the society wants to gain a market for its own members, for the texts it focuses on, or wishes to distribute the texts of its members (or certain key authors) on the market. An especially important tool for this is the press; either the society itself creates a magazine (yearbook, publishing house, etc.), or it will be clustered around an existing entity (publishing house) to assist its work and, at the same time, provide access to the market for its members (or their protégés)." (Kálmán C. 2014: 41)

On the basis of the above, the following questions and hypotheses are formulated when investigating the activities of the La Fontaine Society:

1. The members of the society included the leading personalities of Hungarian literary life. Their presence clearly increased the prestige of the society. In parallel with this finding, the question arises: why did the members consider it important to join the society? This question is also addressed when the weight of the Finnish and Estonian literature, as well as the activity of the Finnish and Estonian members are examined.

2. The society also defined itself as an organisation of translators. At their events, translators played a prominent role (their names appeared on the program books), and in addition, other arts (theatre, music) were represented as well. These multidisciplinary events also served to distinguish the La Fontaine Society from other contemporary societies with similar profiles.

3 . The society treated the publication of texts considered important as a priority. In addition to the papers entitled Literatura and Magyarság, they also published articles in daily newspapers. However, the material conditions for more serious book publishing were only established by the end of the 1920s. How did they select texts for translation and publishing?

4. In recent years, exploring the beginnings of the discipline, as well as the activities of early institutions (papers, societies, etc.) have become an integral part of the self-critical discourse of comparative literature. What lessons can be drawn for thinking and speaking about comparative literature by reconsidering the forgotten tradition - in our case, examining the activities of the La Fontaine Society? 


\section{The La Fontaine Society}

In the following, I will review the first ten years of the Society's activity of a quarter century. The reason for this, apart from the space limitations of this study, was that there was a change in the society's profile and, one might say, in its management, in 1932. Béla Vikár will be the chair of the society at that time, and Imre Bokor will take over as general secretary, while Dezső Kosztolányi will be elected co-chair. The change in the profile of the society was not independent of the social, economic and political context. Improved economic conditions were also needed, for example, for the society to be able to prepare for the second decade of its operations with more serious book publishing plans. In the second part of the 1920s, the intensified opening in Hungarian cultural policy also created a favourable atmosphere for the activities of an organization that defines itself as a world literature society.

\subsection{On the Circumstances of the Foundation}

The society was founded in 1920 to publish La Fontaine's tales. Most of the tales were translated by one of the founders, Béla Vikár, and some others by Andor Kozma and Árpád Zempléni. In order to publish the tales, in January 1919 Vikár turned to the Hungarian Academy of Sciences. One of the reasons for the publication of the translation was the $300^{\text {th }}$ anniversary of the birth of Jean La Fontaine in the upcoming year of 1921, the other one being the lost World War I. Vikár lobbied for publication by referring to both, with the latter being emphasized. He believed that this way the friendship and sympathy of the French people/politicians for the Hungarians could be gained and restored: "Honourable Academy, Currently we do not live in times when we can make use of conventional tools. "Recovering, at least in part, the traditional Hungarian friendship of the French nation is a vital issue for us. We wanted to serve this purpose by translating the tales, something that the marquis of Fontenay, former French Consul General in Budapest thought of, when he came to us with the idea of this edition. There is no doubt that in the event of the plan becoming public, in the French public opinion the sympathy for our nation will manifest again." (Vikár to Hungarian Academy of Sciences, Budapest, January 29, 1919, highlighted by V. P. I.)

In the end, all of La Fontaine's tales were first published in one volume in 1929 at the Dante publishing house with Vikár's foreword, and then, for the second time, in 1942, with the introduction of János Hankiss. The founding of the society was not limited to the intention to publish the translation volume. Béla Vikár was always an advocate of the plans he called "big businesses". At the end of the $19^{\text {th }}$ century, he can be found in many similar "big businesses": founding papers or 
organizing literary life under less formal conditions. Although these plans were either never implemented or very short-lived for mainly material reasons, they proved to be useful for Vikár in terms of networking. Among the Finnish members of the La Fontaine Society, we can mainly see people with whom Vikár already made contact at the end of the $19^{\text {th }}$ century and at the turn of the century. Eino Leino, Juhani Aho, Otto Manninen or Karle Krohn were at the forefront of contemporary Finnish intellectual life. Vikár continuously asked for and received texts for publication from them for the journals Élet and Westöstliche Rundschau edited by him. He also used this experience and social capital in organizing the La Fontaine Society.

In the life of the society, the line of its members expanded on the Hungarian side as well, including people belonging to the contemporary Hungarian literary centre: Dezső Kosztolányi, Mihály Babits, Jenő Heltai, Lőrinc Szabó or even Attila József. ${ }^{3}$ Antal Radó, Pál Gulyás, János Hankiss and János Csengery are also among the members as translators and literary interpreters.

\section{Béla Vikár's Letters}

In the following, I examine the letters written by Vikár between 1920 and 1930, which impacted the activities of the La Fontaine Society in some form. The addressees of the letters are: Mihály Babits, György Kürthy, ${ }^{4}$ the Hungarian Academy of Sciences, Vilma R. Mányoki, ${ }^{5}$ Ede Bresztovszky, ${ }^{6}$ Onerva L., ${ }^{7}$ Otto Manninen, ${ }^{8}$ Larin-Kyösti, ${ }^{9}$ Eino Leino, ${ }^{10}$ Viljo Tarkiainen, ${ }^{11}$ Yrjö Wichmann, ${ }^{12}$ E. A. Tunkelo, ${ }^{13}$ E. N. Setälä, ${ }^{14}$ Gyula Weöres ${ }^{15}$ and Willem Grünthal-Ridala. ${ }^{16}$

\subsection{Hungarian Addressees}

The best known Hungarian addressee is Mihály Babits. According to Vikár's letters, he actively participated in the activities of the society. He held several lectures at the meetings, for instance, on the ones about Byron and Pushkin, or at the matinees dedicated to the translators János Csengery and Károly Szász. At the evening dedicated to Dante, he had a major role not only as a translator of Dante, but he was also present as a poet with his original poems. In 1924, his name also came up as a candidate for the position of co-chair. Unfortunately, the letters revealed do not answer why this was not finally realized. The most obvious explanation seems to be that Babits himself did not want to make such a commitment to the society. He might have not considered the La Fontaine Society significant enough to take up a leading role in it, or he simply did not have time to do it because of his editorial duties and functions in other societies. This may be 
supported by the fact that although Babits was the editor-in-chief of the journal Nyugat at that time, the journal did not commit to publishing texts considered important by the society. Another explanation may be that in 1925 Babits worked on the revival of the Vörösmarty Academy, which was founded in 1918 and then banned during the Hungarian Soviet Republic. The objectives of the Academy have been in line in many respects with the objectives of the La Fontaine Society, especially in terms of international relations. At the same time, we must also see that the prominent members of the banned Vörösmarty Academy joined the La Fontaine Society or the János Vajda Society founded in 1926.

As the editor of Népszava, Ede Bresztovszky represented the press, while György Kürthy was responsible for associated arts.

The letters to the Hungarian Academy of Sciences are related to room requests. The La Fontaine Society held its meetings in the building of the Academy. In other words, the society was important enough to request a room from the Academy. In fact, Vikár tried to make this request permanent. It was especially important that members from the countryside, who were ordinary members of the Hungarian Academy of Sciences, could also attend the La Fontaine Society's events when traveling to academic meetings.

It can be said in relation to the other Hungarian addressees that Vikár corresponded with them regarding the society's administrative and program organization matters. Vilma R. Mányoki was one of the secretaries. The letters sent to her refer to the location of the programs, the payments to the invited speakers, and do not concern the content of the events to be held. Although he is not among the addressees during the examined period, József Faragó was the other significant secretary of the society. Mányoki and Faragó had strong Finnish relations, the latter having a Finnish wife. Mányoki was preoccupied with the Finnish relations only later, during World War II, and he also held lectures on Finnish works, and he even wrote about them. Due to his Finnish language competence, Faragó became Vikár's assistant in writing and correcting Finnish letters and texts.

As the Hungarian lector at the University of Helsinki, Gyula Weöres also strengthened Finnish relations.

\subsection{The Finnish and Estonian Addressees}

The letters to foreign addressees show a more heterogeneous picture. In a letter to Tunkelo, Vikár offered cooperation with the Finnish Literary Society. The strongest argument in the letter was that Finnish literature played a prominent role in the La Fontaine Society's meetings. As an example, two Finnish meetings were mentioned, where in addition to the writer of the letter, Aladár Bán contributed as a translator, and Yrjö Liipola ${ }^{17}$ as a performer. 
E. N. Setälä was an old friend of Vikár's, they already corresponded in the 1890s. During the examined period, Setälä will play a role among the addressees as a Finnish envoy accredited for Hungary as well. Although most of Vikár's letters are written to Setälä, in this decade we can hardly find any that are addressed to him. And even those are of professional relevance. At the beginning of 1929, he invited Setälä to a Northern evening in May. In addition to Norwegian and Swedish literature, Finnish and Estonian literature were also included in the draft program. Vikár emphasized that Finnish literature is the most important among the listed Northern ones. In the second invitation, Norwegian did not appear, and finally, the letter reporting on the event reveals that Estonian literature was also missing from the program of the evening. Northern literature was represented by Swedish and Finnish literature. Vikár also turned to Setälä with a French official request to acknowledge the 10-year-old La Fontaine Society and its pacifist work in some words of appreciation. Although the official language of the society was Hungarian, it was emphasized in the statutes that the given foreign language could be used for foreign correspondence. The official requests sent to Setälä show that they corresponded with foreign partners in French. In addition to the Hungarian one, the seal of the society included its French name as well.

In Vikár's view, the pacifist work of a world literature society meant concluding in and nurturing relations between peoples/nations. Translators play a prominent role in this work and task, as they form the bridge between peoples/nations. In addition to translating each other's literature, having them translated and presenting them, this endeavour was materialized in the form of a policy of advocacy in the self-determination of the society - an association of translators.

Among the listed addressees, Yrjö Wichmann linguist was not present as a translator or member of the La Fontaine Society. Vikár's and Wichmann's correspondence, similar to that of Setälä, preceded the foundation of the society. $\mathrm{He}$ used Wichmann mostly as a mediator during this period. He was well-known person of the Finnish intellectual life, who could help with lobbying, so that classical and contemporary Finnish literary works could be published in Hungarian translation with Finnish funding. In lobbying in Finland, in addition to Wichmann, he also hoped for help from the Hungarian lector of the University of Helsinki, Gyula Weöres. From 1929, he counted on receiving support with their help for the 1935 second edition of Kalevala. He rarely turned to Setälä in financial matters like this one, although Setälä, who was also a politician, seemed to be the most competent person in this field. The fact that he did not address his requests to him was probably due to personal reasons: Setälä had previously rejected or ignored too many of Vikár's similar requests.

Gyula Weöres appears also as a translator among the addressees. Vikár asked him to translate contemporary Finnish short prose, which was also published in the paper Magyarság. Their correspondence shows how a piece of work was 
selected for translation. The proposal could come from either a person representing the society or the translator, and the concrete decision was preceded by a shorter or longer negotiation. In the case of contemporary Finnish works, such as those by F. E. Sillanpää, Maila Talvio, Larin-Kyösti or Arvid Järventaus, it took a little longer to select the text. In the case of classics, this took less time. The correspondence with Weöres also shows that the rules for the election of members laid down in the statutes were also applied for external members. The number of working ordinary members has been maximized for sixty people. New members were elected by secret ballot based on the recommendation of two ordinary members. Only those members were allowed to join the society who "had created something in scientific, scholarly or belletrist literature, or in any branches of art, and who, according to the presidential council, had been recognized as an important author." Following the general assembly resolution, the new member had to hold an inaugural presentation "on the subject area in which they have demonstrated success so far. Performers or musicians are required to participate free of charge at one of the Society's public concerts as their inaugural presentation."

In the case of foreign members, if they were unable to attend an event, their work was read by a local member or actor at one of the meetings of the society.

On the Finnish and Estonian side, Willem Grünthal-Ridala and Otto Manninen were honorary members of the society. They also received an ornate diploma to prove this. The Estonian contact person, Grünthal-Ridala was the Estonian lector at the University of Helsinki at that time. Vikár wrote to him on behalf of the society preparing for its 10-year anniversary: "At the end of September, the La Fontaine our Society becomes 10 years old. On this occasion, we would like to expand our society's work space. We can create the international academy of translators if our foreign members join our plans. Now we have to choose new members in addition to those who are already members of our academy and new members from among those who are already members, that is, in the case of Estonia, from among you. The proposal should be made in writing, taking into account the merits of the stakeholders." (Vikár to Grünthal-Ridala, April 16, 1930) This was one way of involving new members in the society's work. We may also say that there were cultural policy reasons in the background, as Vikár's idea was that Finland and Estonia, with a sufficient number of members, would thus create a separate section to organize local literary evenings. Similar member organizations were established in different cities of Hungary, for example in Debrecen, led by János Hankiss in 1926. He wanted to appoint Grünthal-Ridala to lead the Estonian section, and Otto Manninen to lead the Finnish section.

As far as Manninen is concerned, he was present at the various programs of the La Fontaine Society not only because of his translations from Hungarian, but also for his Finnish translations of the Iliad or Molière's plays. 
In a letter to Eino Leino, Vikár, in addition to reporting on the success of a reading event in Györ, which included Leino's poem in his own translation, lobbied for the release of the Finnish anthology that only appeared in the 1930s.

Larin-Kyösti's presence at the La Fontaine Society's events by the 1920s is less characteristic. He presented some of his poems only in 1929. Vikár began to create a more serious market for his works, mainly for those published in German only later, in the 1930s.

\section{A Literature Society or More?}

Although the word literature is officially included in the name of the La Fontaine Society, its activity was more diverse already in the first decade. There is a reference to this in the last paragraph of its statutes, which reads as follows: "advocacy of all kinds of literature and art, distribution of theatrical, film and literary works, and promotion of their sale at home and abroad."

\subsection{The Presence of Other Arts}

In this respect, it is worth referring to the La Fontaine Society entry of the $\mathrm{Ma}$ gyar szinházmüvészeti lexikon (Hungarian theatre lexicon): "their undertaking on stage was the Játékszín, their regular site was the big hall of the Vasúti és Hajózási Klub (Csengery Street 68.). At these performances they presented Béla Paulini's Patkó Bandi (1927), Józsi Jenő Tersánszky's Ásit az igazság (1928), János Kodolányi’s Fehér fecske (1928), Aurél Kárpáti's A bünös kaptafa (1928). The La Fontaine Society was also associated with the performance of Oidipusz király at the lake from the zoo (1924) and the staging of Goethe's Iphigenia in Tauris at the Alsómargitszigeti Szabadtéri Színapad (1928)." All these characterized the society's first decade. In addition to the specific stage works, other arts represented themselves at literary evenings and matinees: usually professional actors read the translations, and singers performed. In December 1921, Dagmar Parmas ${ }^{18}$ sang Finnish songs, and Finlandia by Sibelius made the Northern (Swedish-Finnish) meeting even more diverse.

The process of selecting plays was similar to the selection of works to be translated: the authors or the society mutually recommended plays to the director and/ or company. A good example of this is the letter from Béla Vikár to György Kürthy: "We are fortunate to send 3 one-act character plays (by Bokor Imre) owned by the La Fontaine Literature Society to your theatre with the note that we should organize together an evening of literary celebration based on these - and some other musical pieces" (Vikár to György Kürthy, April 8, 1924). 
So far, I have not found any information as to whether Finnish or Estonian plays were included in their repertoire, although they read parts of drama translations on various occasions. In 1923, Vikár read parts of Maria Jotuni's drama entitled Miehen kylkiluu in his own translation, according to a letter written to Viljo Tarkiainen, with great success.

The presence of other arts at the programs resulted in more public-friendly events.

\subsection{Book Publishing}

The society paid special attention to the delivery of literary texts to viewers/readers/listeners. In the first decade of its operation, the translation by Aladár Bán of the Estonian epic, Kalevipoeg was published in 1929. The Hungarian translation was already complete in 1917. Vikár was asked to evaluate the manuscript submitted to the Hungarian Academy of Sciences, who wrote a thorough analysis of the translation of several pages, in which he compared the Hungarian text with the Estonian one.

Among the books published in the 1920s, we can also find the volume collecting La Fontaine's tales. As I have mentioned earlier, the primary objective of the society was to publish these tales. However, they were only published in 1929 with Jenő Haranghy's illustrations. Vikár's objectives also included the translation of the tales into Estonian and Finnish. In his letters to Otto Manninen and Grünthal-Ridala, he referred to this several times. He wanted Manninen for the translation, and Grünthal-Ridala was considered as an intermediary. In addition to the literary value of La Fontaine's tales, a common book publishing project was behind Vikár's plan. He imagined the publication of non-Hungarian translations featuring the already existing Haranghy illustrations. This was not realized. The international congress of literary translation planned at the time of its foundation was also cancelled due to a lack of money. This would have provided an opportunity for the translators to meet, while it would have also served as an intellectual workshop where translators and literary mediators and experts of literature could become familiarized with each other's literature in order to facilitate the selection of works worthy of translation for the future.

Vikár wrote about the idea of creating a publishing body for the first time in a letter to Weöres in April 1930. A publishing house would have created the possibility of more regular publishing. However, book publishing will only become more emphasized in the second decade of the society's existence. 


\section{Summary and Conclusions}

French literature and culture played a prominent role in the first ten years of the La Fontaine Society's activity. This might seem to be natural when we consider that the name of the society includes La Fontaine's name, or that the official correspondence with foreign authors was in French. It is also characteristic for the first ten years that in addition to French literature, Finnish literature also played an important role. If we look for lessons to be learned from studying the activities of the La Fontaine Society, reflecting on the self-critical way of comparative literature, it should be done in the context of the relationship between large and small literatures, and literature in general, as well as the key concepts of reciprocity. By large literatures I mean the literatures with a central role in Europe. The Finnish and Estonian literature can be categorized as small literatures. In my view, however, the weight and presence of a certain literature at the events were not determined by its position in the European literature, but rather by the network of regular members within the society. With the help of personal acquaintances, they were able to attract more creators, or even literatures. In order to do this, of course, there was a need for openness on the behalf of the administration of the society. After all, turning to the large literatures is practically coded into the life of a world literature society. However, the interest of small literatures for each other is a less obvious operational policy in terms of reciprocity. When looking for distinctive features of the La Fontaine Society, this should also be considered.

The multidisciplinary nature of the events of the society and the presence of other arts were not only characteristic of the examined society. The participation of actors, performers and singers on various occasions was characteristic of almost all literary societies operating in the first half of the $20^{\text {th }}$ century. The differences are mostly to be found in the proportions and objectives. In the case of the La Fontaine Society, this was a goal assumed in the statutes. Another one of their distinctive features was that they tried to avoid being Budapest-centred. This, in addition to advocating for the organization of certain sections in the countryside, was also shown by the fact that various programs travelled to other cities.

As far as the place of Finnish and Estonian literature is concerned, the platform is common: both of them appear as the literature of the peoples of related languages. At the same time, we have to see the differences: in the plans, Estonian always appears with Finnish, but Estonian is often absent from the implementation phase, while Finnish is included within the literature of Northern countries. 


\section{References}

Kálmán C., György 2014. Dísz-funkciók: irodalmi társaságok a 20. század elején. Partitúra (2) $39-50$.

Laczkó, András 1989. Vikár Béla a La Fontaine Társaságban. Új Írás (10) 85-93.

La Fontaine Irodalmi Társaság a nemzetek szellemi együttmüködésének elösegitésére alapszabályai. Budapest, 1936.

Székely, György et al. 1994. Magyar színházmüvészeti lexikon. Budapest: Akadémiai.

Varga P., Ildikó (red., ed.) 2017. Vikár Béla levelei. EME, Kolozsvár.

\section{Notes}

1 Béla Vikár (1859-1945) stenographer, ethnographer, translator, cultural organizer. As an ethnographer, he was the first to collect data with a phonograph, and he translated from several languages. His best-known work is the Hungarian translation of the Finnish national epic, Kalevala. In addition to Finnish, he also translated from French, German, Estonian, Italian, Dutch, Norwegian, Turkish and Georgian. He is founding member of the La Fontaine Society and the Goethe Society with German connections.

2 Varga P. Ildikó (red., ed.): Vikár Béla levelei (Béla Vikár's Letters). EME, Kolozsvár/ Cluj-Napoca, 2017.

3 In relation to Attila József's election as a member, it is written in several places that after this the La Fontaine Society could not hold its meetings in the rooms of the Hungarian Academy of Sciences. However, Vikár's letters do not support this finding. Attila József was elected member in October 1936 based on the proposal made by Lörinc Szabó, and the first time when the Academy did not provide a room was on September 15, 1939. The reason for this was World War II. As chairman of the society at the time, Vikár argued unsuccessfully with the idea of the apolitical meeting concerning only "literary and economic issues".

4 György Kürthy (1882-1972) actor, theater director (at the time of writing the letter: at Pécs)

5 Rafaelné Mányoki Vilma (1892-1969) professor, from 1924 secretary of the La Fontaine Society

6 Bresztovszky Ede (1889-1963) associate and editor of the journal Népszava

7 L. Onerva - Hilja Onerva Lehtinen (1882-1972) Finnish poet, literary translator, critic

8 Otto Manninen (1872-1950) regular translator into Finnish of Hungarian literature. Finnish readers were first introduced to the poets Petöfi, Arany and Madách through his interpretation.

9 Karl Gustaf Larsson (1873-1948) Finnish writer, poet, he published under the name Larin-Kyösti.

10 Eino Leino (1878-1926) Finnish poet

11 Viljo Tarkiainen (1879-1951) Finnish literary historian, university professor

12 Yrjö Wichmann (1868-1932) Finno-Ugricist, linguist, university professor at the University of Helsinki. His wife is Julie/Zsüli Herrmann, Antal Herrmann daughter.

13 E. A. Tunkelo (1870-1953) linguist, at this time librarian and manuscript librarian at the Finnish Literary Society (SKS)

14 Emil Nestor Setälä (1864-1835) Finnish linguist, university professor, politician, diplomat. 
15 Weöres Gyula (1899-1989) professor, literary translator, Hungarian lector at the University of Helsinki

16 Willem Grünthal-Ridala (1885-1942) Estonian writer, linguist, literary scholar, from 1923 until his death he was the Estonian lector at the University of Helsinki

17 Yrjö Liipola (1881-1971) sculptor. He lived in Hungary for a long time and returned to Finland in 1934.

18 Dagmar Parmas (1886-1940) Finnish singer, actress 